\title{
Hubungan Kadar Laktat dan Albumin dengan Mortalitas dan Morbiditas Pasien Perforasi Ulkus Peptikum
}

\author{
Gisela Karina $^{1}$, Reno Rudiman ${ }^{2}$, Tommy Ruchimat ${ }^{2}$ \\ ${ }^{1}$ Departemen Bedah, Universitas Padjadjaran, Bandung \\ 2 Divisi Bedah Digestif, Departemen Bedah, Universitas Padjadjaran, Bandung \\ ${ }^{3}$ Divisi Bedah Digestif, Departemen Bedah Onkologi, Universitas Padjadjaran, Bandung
}

\begin{abstract}
Abstrak
Latar Belakang.Perforasi ulkus peptikum merupakan kondisi emergensi di seluruh dunia, dengan tingkat mortalitas sampai dengan 30\%. Penilaian kadar laktat dan albumin dalam darah diharapkan dapat menjadi suatu perangkat penilai untuk memperkirakan tingkat mortalitas dan morbiditas pasien perforasi ulkus peptikum. ${ }^{3,5}$

Metode. Desain analitis menggunakan metode kohort prospektif dengan analisis korelasi hubungan kadar albumin dan laktat terhadap kejadian mortalitas dan morbiditas pasien perforasi ulkus peptikum di RS. Hasan Sadikin. Subjek penelitian dilakukan dengan cara consecutive sampling. Populasi terjangkau adalah pasien dengan diagnosis klinis perforasi ulkus peptikum yang datang ke Unit Gawat Darurat RSHS pada periode 1 Februari 2018 - 28 Februari 2019. Uji statistik menggunakan uji analisis regresi logistik bivariat.

Hasil. Didapatkan 40 pasien, mayoritas berjenis kelamin laki - laki (35 pasien), sisanya perempuan dengan rentang usia 22 - 80 tahun. Didapatkan 11 pasien meninggal $(27.5 \%$ dari sampel). Pasien mati memiliki rata - rata kadar laktat $6,4 \pm 3,7 \mathrm{mmol} / \mathrm{L}$ dan rata - rata kadar albumin $2,1 \pm 0,4 \mathrm{mg} / \mathrm{dL}$. Morbiditas pada penelitian ini ialah komplikasi hospital acquired pneumonia pasca operasi. Hasil uji Wald membuktikan bahwa kadar laktat berhubungan positif secara signifikan dengan mortalitas pasien perforasi ulkus peptikum dengan probabilitas kesalahan statistik sebesar $\mathrm{p}=0,024(\mathrm{p}<0,05)$ dan kadar albumin berhubungan negatif secara signifikan dengan mortalitas pasien perforasi ulkus peptikum dengan probabilitas kesalahan statistik sebesar $p=0,032(p<0,05)$.
\end{abstract}




\section{ARTIKEL PENELITIAN}

Kesimpulan: Kadar laktat berhubungan positif dengan mortalitas pasien namun tidak dengan morbiditas pasien, sedangkan kadar albumin berhubungan negatif dengan mortalitas pasien namun tidak dengan morbiditas pasien.. Semakin tinggi kadar laktat dan semakin rendah kadar albumin, semakin tinggi probabilitas pasien untuk mati.

Kata Kunci: Laktat, albumin, mortalitas, morbiditas, perforasi ulkus peptikum.

(ISSN 2723-7494 J Bedah Indonesia. 2020;48:38-58)

Korespondensi penulis:

Gisela Karina

Departemen Bedah, Universitas Padjadjaran, Bandung

Jalan Pasteur no. 38, Pasteur, Sukajadi, Bandung

Email: giselaks26@gmail.com 


\title{
ARTIKEL PENELITIAN
}

The Relationship between Lactate and Albumin Levels with Mortality and Morbidity in Patients with Peptic Ulcer Perforation

\begin{abstract}
Background: Peptic ulcer perforation is an emergency condition worldwide, with associated mortality rates up to 30\%. Expected lactate and albumin value could be used to predict mortality and morbidity in perforated peptic ulver patient.

Methods: Prospective cohort study with analytics correlation design to assess whether there was a correlation between lactate and albumin value with mortality and morbidity in perforated peptic ulcer patient. The population of this study was all patients who came to the emergency department of Surgery of Hasan Sadikin Hospital Bandung with clinical diagnosis of perforated peptic ulcer, between February 2018 - February 2019 that meet the inclusion criteria and exclusion criteria. Bivariate logistic regression analysis was used to analyses the data.

Results: There were 40 patients who met the inclusion criteria. The majority of patients were male (35 patients), the rest were female with age range $22-80$ years old. There were 11 patients passed away (27.5\%). Mean lactate value was $6,4 \pm 3,7 \mathrm{mmol} / \mathrm{L}$ and mean albumin value was 2,1 $\pm 0,4 \mathrm{mg} / \mathrm{dL}$. Morbidity that was found in this research was hospital acquired pneumonia. Based on Wald test, lactate value was positively corelated significant with mortality of peptic ulcer perforation patient with $p=0.024(p<0.05)$ and albumin value correlated negatively significant with mortality of peptic ulcer perforation patients $p=0.032(p<0.05)$

Conclusion: Lactate value was positively corelated with mortality in peptic ulcer perforation patient but not with morbidity. Albumin value was negatively corelated with mortality in peptic ulcer perforation patient but not with morbidity. Higher lactate value and lower albumin value, the higher probability of mortality in perforated peptic ulcer patients.
\end{abstract}

Keywords: Lactate, albumin, mortality, morbidity, perforated peptic ulcer 


\section{ARTIKEL PENELITIAN}

\section{Latar Belakang}

Perforasi pada ulkus peptikum merupakan kondisi emergensi di seluruh dunia, dengan tingkat mortalitas sampai dengan $30 \%$. Pada setiap negara, terdapat perbedaan penyebab, kondisi demografis, letak perforasi, dan tingkat mortalitas yang berbeda. Berdasarkan data di rekam medis Rumah Sakit Hasan Sadikin, Bandung, didapatkan 71 pasien perforasi ulkus peptikum pada tahun 2016 dan 24 pasien meninggal (33\%).

Dengan penilaian tingkat keparahan preoperatif, penatalaksanaan yang tepat dan segera dapat dilakukan untuk meningkatkan prognosis pasien, khususnya pasien dengan perforasi ulkus peptikum. ${ }^{1}$

Pasien perforasi ulkus peptikum dapat mengalami berbagai morbiditas pasca operatif, yang berdampak bagi pasien diantaranya infeksi luka operasi, ileus pasca operatif, kebocoran setelah penjahitan primer gaster, serta hospital acquired pneumonia dalam masa perawatan. $^{2}$

Berbagai sistem skoring telah dapat digunakan untuk memprediksi mortalitas pada pasien dengan perforasi ulkus peptikum, diantaranya sistem skoring berdasarkan American Society of
Anesthesiologist (ASA), Boey score, dan Peptic Ulcer Perforation (PULP) score, namun tidak satupun dikatakan lebih superior dari sistem skoring yang lain untuk memprediksi tingkat mortalitas. ${ }^{3}$

Keterbatasan dari sistem skoring ASA ialah subjektifitas-nya dan tidak spesifik untuk dapat memprediksi mortalitas pasien perforasi ulkus peptikum. Sistem skoring PULP menilai data objektif yang berhubungan dengan tingkat keparahan penyakit dan serta skoring ASA, namun sistem skoring ini lebih kompleks dan tidak praktis. Sistem skoring Boey, walaupun lebih praktis, namun nilai prediktibilitasnya ditemukan bervariasi pada beberapa penelitian. $3,9,16,17$

Suatu perangkat penilai untuk mengidentifikasi pasien - pasien yang menjalani operasi pada unit perawatan bedah dibutuhkan untuk optimalisasi pelayanan medis. Penanda biologis (biomarker) dapat digunakan sebagai alat diagnostik yang objektif dan tersedia dengan cepat untuk mengidentifikasi pasien - pasien dengan infeksi abdomen yang membutuhkan perhatian khusus dalam perawatan intensif karena tingkat mortalitas dan morbiditas yang lebih besar. Penanda biologis dapat 


\section{ARTIKEL PENELITIAN}

menggambarkan respons pasien terhadap infeksi dan secara tidak langsung tingkat keparahan infeksi. ${ }^{4}$

Berdasarkan penelitian I. Smith pada tahun 2001, dengan mengukur kadar laktat serta base excess, atau kombinasi dari keduanya dapat memperkirakan prognosis pada pasien - pasien kritis di ICU ${ }^{5}$. Namun belum ada penelitian khusus yang membandingkan pengaruh kadar laktat terhadap mortalitas dan morbiditas pasien perforasi ulkus peptikum.

Pada penelitian pasien - pasien dengan perforasi ulkus peptikum yang dilakukan oleh Kenneth Thorsen tahun 2014 di Finlandia mengenai prediktor mortalitas terbaik pada pasien perforasi ulkus peptikum yang membandingkan faktor - faktor klinis dan tiga sistem skoring (ASA, PULP, Boey score), hipoalbumin dapat merupakan prediktor utama dan kuat untuk menilai tingkat mortalitas pasien. ${ }^{3}$ Namun penelitian tersebut dilakukan pada populasi yang berbeda dan belum ada penelitian yang dilakukan pada populasi di Jawa Barat khususnya di rumah sakit Hasan Sadikin Bandung.
Pada penelitan oleh Gonzalez et al pada tahun 2016 pada pasien perdarahan saluran cerna bagian atas non variceal, serum albumin dapat digunakan sebagai perdiktor mortalitas dan sebanding dengan skore Rockall. ${ }^{12}$ Penilaian kadar serum albumin pada $24-48$ jam setelah pasien masuk sama akuratnya dengan skoring APACHE II dalam memprediksi mortalitas.

Berdasarkan teori dan penelitian sebelumnya, penulis terdorong untuk melakukan penelitian mengenai hubungan laktat dan albumin dengan mortalitas dan morbiditas pada pasien pasien dengan perforasi ulkus peptikum khususnya di rumah sakit Hasan Sadikin, Bandung dan apakah indikator ini dapat dijadikan sebagai perangkat screening bagi pasien - pasien perforasi ulkus peptikum yang datang ke unit gawat darurat.

Penelitian ini bertujuan untuk membantu menemukan identifikasi faktor prognostik secara dini (kadar laktat dan albumin) pada pasien perforasi ulkus peptikum, sehingga diharapkan dapat dilakukan intervensi medis secara dini guna mengurangi morbiditas dan mortalitas. 


\section{ARTIKEL PENELITIAN}

\section{Metode}

Penelitian observasional prospektif (cohort) dengan analisis korelasi hubungan kadar albumin dan laktat terhadap kejadian mortalitas dan morbiditas pasien perforasi ulkus peptikum di RSHS.

Penelitian dilakukan di Subdivisi Bedah Digestif Departemen Bedah RSUP dr. Hasan Sadikin, Bandung pada bulan periode 1 Februari 2018 - 28 Februari 2019. Subyek penelitian adalah semua pasien berusia lebih dari 19 tahun dengan diagnosa klinis perforasi ulkus peptikum yang masuk ke unit gawat darurat RSHS dan menjalani perawatan di RSHS pada periode 1 Februari 2018 - 28 Februari 2019 serta bersedia mengikuti penelitian setelah mendapatkan penjelasan.

Dilakukan pengambilan darah serum laktat pada saat pasien datang dan albumin yang diambil lebih dari 24 jam setelah terjadinya perforasi.

Ukuran sampel dalam penelitian ini ditentukan berdasarkan prediksi nilai koefisien korelasi, ditetapkan sebanyak 40 pasien. Dilakukan pengumpulan dan analisa data univariate, bivariate, dan multivariate.
Hasil

Sampel yang dilibatkan dalam penelitian ini adalah sebanyak 40 pasien (Tabel 1) perforasi ulkus peptikum yang masuk ke Unit Gawat Darurat dan menjalani perawatan di RSUP Dr. Hasan Sadikin selama periode penelitian.

(Tabel 1) Hasil analisis mortalitas pasien perforasi ulkus peptikum menunjukkan bahwa terdapat 11 pasien yang mati atau $27,5 \%$ dari sampel, sedangkan sisanya hidup, yaitu sebanyak 29 pasien atau $72,5 \%$ dari sampel. Adapun hasil analisis morbiditas pasien yang diukur dari ada/tidaknya komplikasi HAP (hospital acquired pneumonia) menunjukkan bahwa terdapat 7 pasien yang mengalami komplikasi HAP atau $17,5 \%$ dari sampel, sedangkan sisanya tidak mengalami komplikasi HAP, yaitu sebanyak 33 pasien atau $82,5 \%$ dari sampel.

(Tabel 2) Mayoritas pasien berjenis kelamin laki-laki (35 pasien atau 87,5\% dari sampel), dan sisanya perempuan. Pasien yang mati didominasi pasien lakilaki, yaitu sebanyak 9 pasien atau $81,8 \%$ dari total pasien yang mati (11 pasien). Pasien yang hidup juga didominasi 


\section{ARTIKEL PENELITIAN}

pasien laki-laki, yaitu sebanyak 26 pasien atau $89,7 \%$ dari total pasien yang hidup (29 pasien). Seluruh pasien yang mengalami komplikasi HAP adalah pasien laki-laki, yaitu sebanyak 7 pasien atau $100,0 \%$ dari total pasien yang mengalami komplikasi HAP. Pasien yang tidak mengalami komplikasi HAP juga didominasi pasien laki-laki, yaitu sebanyak 28 pasien atau $84,8 \%$ dari total pasien yang tidak mengalami komplikasi HAP (33 pasien).

(Tabel 3) Rata-rata usia pasien adalah $59,9 \pm 14,8$ tahun dengan median 61,5 tahun dan rentang usia antara $22-80$ tahun. Pasien yang mati memiliki ratarata usia yang lebih rendah $(54,7 \pm 15,2$ tahun) daripada pasien yang hidup $(61,9$ $\pm 14,5$ tahun). Adapun pasien yang mengalami komplikasi HAP memiliki rata-rata usia yang lebih tinggi $(65,7 \pm$ 7,3 tahun) daripada pasien yang tidak mengalami komplikasi $(58,7 \pm 15,8$ tahun).

(Tabel 4) Rata-rata kadar laktat pasien adalah 3,4 $\pm 2,8 \mathrm{mmol} / \mathrm{L}$ dengan median 2,3 $\mathrm{mmol} / \mathrm{L}$ dan rentang kadar laktat antara $0,9-16,7 \mathrm{mmol} / \mathrm{L}$. Pasien yang mati memiliki rata-rata kadar laktat sebesar $6,4 \pm 3,7 \mathrm{mmol} / \mathrm{L}$, sedangkan pasien yang hidup memiliki rata-rata kadar laktat sebesar 2,2 $\pm 1,1 \mathrm{mmol} / \mathrm{L}$. Adapun pasien yang mengalami komplikasi HAP memiliki rata-rata kadar laktat sebesar 3,7 $\pm 1,2 \mathrm{mmol} / \mathrm{L}$, sedangkan pasien yang tidak mengalami komplikasi HAP memiliki rata-rata kadar laktat sebesar 3,3 $\pm 3,1 \mathrm{mmol} / \mathrm{L}$.

(Tabel 4) Rata-rata kadar albumin pasien adalah 2,4 $\pm 0,6 \mathrm{mg} / \mathrm{dL}$ dengan median 2,3 mg/dL dan rentang kadar albumin antara 1,1 - 3,7 mg/dL. Pasien yang mati memiliki rata-rata kadar albumin sebesar 2,1 $\pm 0,4 \mathrm{mg} / \mathrm{dL}$, sedangkan pasien yang hidup memiliki rata-rata kadar albumin sebesar 2,5 $\pm 0,6$ $\mathrm{mg} / \mathrm{dL}$. Adapun pasien yang mengalami komplikasi HAP memiliki rata-rata kadar albumin sebesar 2,5 $\pm 0,7 \mathrm{mg} / \mathrm{dL}$, sedangkan pasien yang tidak mengalami komplikasi HAP memiliki rata-rata kadar albumin sebesar 2,4 $\pm 0,6 \mathrm{mg} / \mathrm{dL}$.

(Tabel 5) Perbandingan kadar laktat berdasarkan mortalitas dan morbiditas pasien dilakukan dengan uji MannWhitney sesuai hasil uji normalitas (uji Shapiro-Wilk) yang menunjukkan bahwa distribusi data kadar laktat teruji tidak normal $(\mathrm{p}<0,05)$, baik pada pasien yang mati maupun pasien yang hidup, 


\section{ARTIKEL PENELITIAN}

demikian juga pada pasien yang tidak mengalami komplikasi HAP. Sedangkan perbandingan kadar albumin berdasarkan mortalitas dan morbiditas pasien dilakukan dengan uji $t$ independen sesuai hasil uji normalitas (uji Shapiro-Wilk) yang menunjukkan bahwa distribusi data kadar albumin teruji normal $(\mathrm{p}>0,05)$, baik pada pasien yang mati maupun pasien yang hidup, demikian juga pada pasien yang mengalami komplikasi HAP maupun pasien yang tidak mengalami komplikasi HAP.

$$
\text { Hasil uji Mann-Whitney }
$$
membuktikan bahwa kadar laktat pada pasien yang mati secara signifikan lebih tinggi daripada pasien yang hidup ( $\mathrm{p}<$ 0,001). Median kadar laktat pada pasien yang mati $(5,0 \mathrm{mmol} / \mathrm{L})$ lebih tinggi daripada pasien yang hidup (1,9 mmol/L). Hasil uji Mann-Whitney juga membuktikan bahwa kadar laktat pada pasien yang mengalami komplikasi HAP secara signifikan lebih tinggi daripada pasien yang tidak mengalami komplikasi HAP $\quad(p=0,0435)$. Median kadar laktat pada pasien yang mengalami komplikasi HAP $(3,4 \mathrm{mmol} / \mathrm{L})$ lebih tinggi daripada pasien yang tidak mengalami komplikasi $\operatorname{HAP}(2,1 \mathrm{mmol} / \mathrm{L})$.

(Tabel 6) Hasil uji $t$ independen membuktikan bahwa kadar albumin pada pasien yang mati secara signifikan lebih rendah daripada pasien yang hidup $(\mathrm{p}=0,0305)$. Rata-rata kadar albumin pada pasien yang mati $(2,1 \mathrm{mg} / \mathrm{dL})$ lebih rendah daripada pasien yang hidup $(2,5$ $\mathrm{mg} / \mathrm{dL})$. Walaupun demikian hasil uji $\mathrm{t}$ independen menunjukkan bahwa kadar albumin pada pasien yang mengalami komplikasi HAP tidak lebih rendah secara signifikan daripada pasien yang tidak mengalami komplikasi HAP ( $\mathrm{p}=$ 0,707). Rata-rata kadar albumin pada pasien yang mengalami komplikasi HAP (2,5 mg/dL) justru lebih tinggi daripada pasien yang tidak mengalami komplikasi $\operatorname{HAP}(2,4 \mathrm{mg} / \mathrm{dL})$.

(Tabel 7) Berdasarkan hasil analisis regresi logistik menunjukkan bahwa koefisien regresi dari kadar laktat bernilai positif. Hasil ini menunjukkan bahwa semakin tinggi kadar laktat, semakin tinggi probabilitas pasien untuk mati. Hasil uji Wald membuktikan bahwa kadar laktat berhubungan positif secara signifikan dengan mortalitas pasien perforasi ulkus peptikum dengan 


\section{ARTIKEL PENELITIAN}

probabilitas kesalahan statistik sebesar $\mathrm{p}$ $=0,024(\mathrm{p}<0,05)$. Berdasarkan hasil analisis juga tampak bahwa koefisien regresi dari kadar albumin bernilai negatif. Hasil ini menunjukkan bahwa semakin rendah kadar albumin, semakin tinggi probabilitas pasien untuk mati. Hasil uji Wald membuktikan bahwa kadar albumin berhubungan negatif secara signifikan dengan mortalitas pasien perforasi ulkus peptikum dengan probabilitas kesalahan statistik sebesar $\mathrm{p}$ $=0,032(\mathrm{p}<0,05)$.

(Tabel 7) Hasil uji Omnibus menunjukkan bahwa kadar laktat dan albumin berhubungan secara signifikan dengan mortalitas pasien dengan probabilitas kesalahan statistik sebesar $\mathrm{p}$ $=0,000(\mathrm{p}<0,05)$. Besarnya variasi probabilitas mortalitas pasien yang dapat dijelaskan oleh kadar laktat dan albumin, sebagaimana ditunjukkan oleh koefisien determinasi Nagelkerke (Nagelkerke $R$ Squared), adalah sebesar 0,868 atau $86,8 \%$. Adapun derajat keeratan hubungan kadar laktat dan albumin dengan mortalitas pasien tergolong sangat tinggi, sebagaimana ditunjukkan oleh akar dari Nagelkerke $R$ Squared yang sebanding dengan nilai koefisien korelasinya, yaitu sebesar $\sqrt{ } 0,868=$ 0,932 (terletak dalam rentang kategori keeratan hubungan yang sangat tinggi menurut klasifikasi Guilford, yaitu: antara $0,90-1,00)$.

(Tabel 8) Hubungan kadar laktat dan albumin dengan morbiditas pasien diuji berdasarkan hasil analisis regresi logistik bivariat. Persamaan model yang diperoleh adalah sebagai berikut:

$\operatorname{Ln}(\mathrm{P} /[1-\mathrm{p}])=\mathrm{b}_{0}+\mathrm{b}_{1}$ Laktat $+\mathrm{b}_{2}$ Albumin $\operatorname{Ln}(\mathrm{P} /[1-\mathrm{P}])=-2,721+$ 0,050.Laktat + 0,403.Albumin

atau

$\mathrm{P}=1 /\left(1+\mathrm{e}^{-\left(\mathrm{b}_{0}+\mathrm{b}_{1} \text { Laktat }+\mathrm{b}_{2} \text { Albumin }\right)}\right)$

$\mathrm{P}=1 /\left(1+\mathrm{e}^{-(-2,721}+\right.$ 0,050.Laktat + 0,403.Albumin))

di mana:

$\mathrm{P}=$ Probabilitas (mengalami komplikasi HAP)

Laktat $=$ Kadar Laktat $(\mathrm{mmol} / \mathrm{L})$

Albumin $=$ Kadar Albumin (mg/dL)

(Tabel 8) Berdasarkan hasil analisis regresi logistik, menunjukkan bahwa koefisien regresi dari kadar laktat bernilai positif. Hasil ini menunjukkan bahwa semakin tinggi kadar laktat, 


\section{ARTIKEL PENELITIAN}

semakin tinggi probabilitas pasien untuk mengalami komplikasi HAP. Walaupun demikian, hasil uji Wald menunjukkan bahwa hubungan positif antara kadar laktat dengan morbiditas pasien perforasi ulkus peptikum tidaklah signifikan dengan probabilitas kesalahan statistik sebesar $p=0,352(p>0,05)$. Berdasarkan hasil analisis juga tampak bahwa koefisien regresi dari kadar albumin bernilai positif, yang berarti semakin tinggi kadar albumin, semakin tinggi probabilitas pasien untuk mengalami komplikasi HAP. Hasil uji Wald menunjukkan bahwa tidak ada hubungan negatif yang signifikan antara kadar albumin dengan morbiditas pasien perforasi ulkus peptikum dengan probabilitas kesalahan statistik sebesar $\mathrm{p}$ $=0,7185(\mathrm{p}>0,05)$.

(Tabel 8) Hasil uji Omnibus menunjukkan bahwa kadar laktat dan albumin tidak berhubungan secara signifikan dengan mortalitas pasien dengan probabilitas kesalahan statistik sebesar $p=0,800(p>0,05)$. Besarnya variasi probabilitas morbiditas pasien yang dapat dijelaskan oleh kadar laktat dan albumin, sebagaimana ditunjukkan oleh koefisien determinasi Nagelkerke
(Nagelkerke $R$ Squared), adalah hanya sebesar 0,018 atau 1,8\%. Adapun derajat keeratan hubungan kadar laktat dan albumin dengan morbiditas pasien tergolong sangat rendah, sebagaimana ditunjukkan oleh akar dari Nagelkerke $R$ Squared yang sebanding dengan nilai koefisien korelasinya, yaitu sebesar $\sqrt{ } 0,018=0,134$ (terletak dalam rentang kategori keeratan hubungan yang sangat rendah menurut klasifikasi Guilford, yaitu: $<0,20)$.

\section{Pembahasan}

(Tabel 1) Selama periode 1 Februari 2018 - 28 Februari 2019, diperoleh 40 pasien yang memenuhi kriteria inklusi dengan diagnosis klinis perforasi ulkus peptikum yang datang ke IGD Bedah / Bagian Ilmu Bedah RSUP Dr. Hasan Sadikin Bandung. Dari Sampel yang ada, terdapat 11 pasien yang mati atau $27,5 \%$ dari sampel, sedangkan sisanya hidup, yaitu sebanyak 29 pasien atau $72,5 \%$ dari sampel.

Berdasarkan data di rekam medis Rumah Sakit Hasan Sadikin, Bandung, didapatkan 71 pasien perforasi ulkus peptikum pada tahun 2016 dan 24 pasien 


\section{ARTIKEL PENELITIAN}

meninggal $(33 \%)$. Terdapat penurunan pada jumlah pasien dengan diagnosa klinis perforasi ulkus peptikum yang datang ke Bagian Ilmu Bedah RSUP Dr. Hasan Sadikin Bandung. Hal ini dapat disebabkan karena sistem rujukan rumah sakit yang sudah berjenjang teratur sehingga pasien tersebut sudah dapat ditangani di rumah sakit tipe $B$.

Adapun morbiditas yang didapatkan dari penelitian ini ialah komplikasi pasca operatif berupa hospital acquired pneumonia dapat memperpanjang masa perawatan pasien. Adapun hasil analisis morbiditas pasien yang diukur dari ada/tidaknya komplikasi HAP (hospital acquired pneumonia) menunjukkan bahwa terdapat 7 pasien yang mengalami komplikasi HAP atau $17,5 \%$ dari sampel, sedangkan sisanya tidak mengalami komplikasi HAP, yaitu sebanyak 33 pasien atau $82,5 \%$ dari sampel.

Rata - rata kadar laktat lebih tinggi pada pasien yang mati dan memiliki komplikasi HAP pasca operatif. Sedangkan, kadar albumin lebih rendah pada pasien yang mati. Namun rata - rata kadar albumin tidak terlalu jauh berbeda antara pasien yang memiliki komplikasi HAP pasca operatif maupun tidak.

(Tabel 8) menjelaskan hubungan kadar laktat dan albumin terhadap mortalitas pasien. Berdasarkan hasil analisis regresi logistik tersebut, tampak bahwa koefisien regresi dari kadar laktat bernilai positif. Hasil ini menunjukkan bahwa semakin tinggi kadar laktat, semakin tinggi probabilitas pasien untuk mati. Hasil uji Wald membuktikan bahwa kadar laktat berhubungan positif secara signifikan dengan mortalitas pasien perforasi ulkus peptikum dengan probabilitas kesalahan statistik sebesar $p$ $=0,024(\mathrm{p}<0,05)$. Berdasarkan hasil analisis juga tampak bahwa koefisien regresi dari kadar albumin bernilai negatif. Hasil ini menunjukkan bahwa semakin rendah kadar albumin, semakin tinggi probabilitas pasien untuk mati. Hasil uji Wald membuktikan bahwa kadar albumin berhubungan negatif secara signifikan dengan mortalitas pasien perforasi ulkus peptikum dengan probabilitas kesalahan statistik sebesar $\mathrm{p}$ $=0,032(\mathrm{p}<0,05)$.

Dari hasil perhitungan statistik tersebut. Kadar laktat dan albumin berhubungan dengan tingkat mortalitas. 


\section{ARTIKEL PENELITIAN}

Semakin tinggi kadar laktat dan semakin rendah kadar albumin maka tingkat mortalitas semakin tinggi.

Hal ini sesuai dengan penelitian terdahulu oleh Smith et al pada tahun 2001 mengenai nilai laktat yang meningkat pada pasien - pasien kritis. ${ }^{5}$ Serta penelitian terdahulu oleh Thorsen et al pada tahun 2014, hipoalbuminemia merupakan prediktor kuat untuk mortalitas. Dan berdasarkan penelitian sebelumnya oleh Horssen, et al pada tahun 2015, peningkatan kadar laktat $>4$ mmol / L berhubungan dengan prognosis yang buruk. Pada penelitian terdahulu oleh Nocholson et al pada tahun 2000, ditemukan konsentrasi serum albumin $<3.4 \mathrm{mg} / \mathrm{dl}$ berhubungan dengan peningkatan tingkat mortalitas $24.6 \%$ dan meningkat menjadi $60 \%$ pada konsentrasi serum albumin $<2.0 \mathrm{mg} / \mathrm{dL}$ 14

Oleh karena itu diperlukan suatu upaya untuk mengontrol kadar laktat dan albumin untuk mengurangi tingkat mortalitas.

Dari penelitian ini, didapatkan data morbiditas berupa komplikasi hospital acquired pneumonia (HAP) pasca operasi sebanyak 7 pasien. Tidak ditemukan data komplikasi infeksi luka operasi ataupun kecoboran pasca operasi. Tabel 9 menjelaskan hubungan kadar laktat dan albumin dengan morbiditas pasien berupa komplikasi hospital acquired pneumonia (HAP) pasca operatif. Berdasarkan hasil analisis regresi logistik tersebut tampak bahwa koefisien regresi dari kadar laktat bernilai positif. Hasil ini menunjukkan bahwa semakin tinggi kadar laktat, semakin tinggi probabilitas pasien untuk mengalami komplikasi HAP. Walaupun demikian, hasil uji Wald menunjukkan bahwa hubungan positif antara kadar laktat dengan morbiditas pasien perforasi ulkus peptikum tidaklah signifikan dengan probabilitas kesalahan statistik sebesar $p=0,352(p>0,05)$. Berdasarkan hasil analisis juga tampak bahwa koefisien regresi dari kadar albumin bernilai positif, yang berarti semakin tinggi kadar albumin, semakin tinggi probabilitas pasien untuk mengalami komplikasi HAP. Hasil uji Wald menunjukkan bahwa tidak ada hubungan negatif yang signifikan antara kadar albumin dengan morbiditas pasien perforasi ulkus peptikum dengan 


\section{ARTIKEL PENELITIAN}

probabilitas kesalahan statistik sebesar $\mathrm{p}$ $=0,7185(\mathrm{p}>0,05)$.

Sedangkan dari penelitian sebelumnya oleh Noguiera et al di Portugal pada tahun 2003, dari 210 pasien didapatkan komplikasi pasca operasi terbanyak ialah infeksi saluran nafas (24 pasien), infeksi luka operasi (12 pasien), dan kebocoran pasca operasi (7 pasien). Hal ini sesuai dengan penelitian penulis, didapatkan data bahwa komplikasi yang ditemukan ialah hospital acquired pneumonia pasca operatif. Dari penelitian tidak didapatkan data infeksi luka operasi maupun kebocoran pasca operatif. Didapatkan perbedaan lokasi penelitian dan jumlah sampel yang didapat antara penelitian terdahulu dengan penulis. ${ }^{2}$

Dari hasil perhitungan statistik tersebut, didapatkan kadar laktat dan albumin tidak berhubungan secara signifikan dengan morbiditas pasien berupa komplikasi hospital acquired pneumonia pasca operatif.

Berdasarkan kajian yang telah dilakukan peneliti, maka penilaian kadar laktat dan albumin dapat digunakan untuk membantu memprediksi mortalitas pada pasien perforasi ulkus peptikum namun tidak signifikan untuk memprediksi morbiditas dalam hal ini berupa komplikasi pneumonia pasca operatif.

\section{Kesimpulan}

Penilaian kadar laktat dan albumin pre operatif dapat membantu memperkirakan prognosis pasien perforasi ulkus peptikum. Kadar laktat berhubungan positif secara signifikan dengan mortalitas pasien sedangkan kadar albumin berhubungan negatif secara signifikan dengan mortalitas pasien perforasi ulkus peptikum.

Morbiditas yang ditemukan pada penelitian ini ialah angka kejadian hospital acquired pneumonia dalam masa perawatan pasca operatif. Kadar laktat dan albumin tidak memiliki hubungan yang signifikan dengan morbiditas komplikasi hospital acquired pneumonia dalam masa perawatan pasca operatif.

\section{Saran}

Peningkatan kadar laktat dan penurunan kadar albumin dapat digunakan untuk memprediksi mortalitas pasien perforasi ulkus 


\section{ARTIKEL PENELITIAN}

peptikum. Diperlukan penelitian lebih

lanjut dengan jumlah sampel yang lebih

banyak untuk mendapatkan gambaran prediksi lebih baik mengenai tingkat

mortalitas dan morbiditas pasien

perforasi ulkus peptikum.

\section{Daftar Pustaka}

1.

Kjetil Soreide, K.T., Ewen M Harrison, Juliane Bingener, Morten $\mathrm{H}$ Muller, Michael Ohene-Yeboah, Jon Arne Soreide, Perforated Peptic Ulcer. Emergency Surgery, 2015(386): p. 1288-98.

2. Noguiera, Carlos, et all,

Perforated Peptic Ulver : Main

Factors of Morbidity and Mortality, 2003, World Journal Surgery, 27.

3. Thorsen, K., J.A. Soreide, and K. Soreide, What is the Best

Predictor of Mortality in

Perforated Peptic Ulcer Disease ? A Population-Based, Multivaariable Regression Analysis Including Three Clinical Soring System. Gastrointestinal Surgery, 2014(18): p. 1261-1268.

4. Alejandro Suarez-de-la-Rica, E.M., Victor Anillo, Eduardo Tamayo, Carlos A. Garcia, Biomarkers (Procalcitonin, CRP, and Lactate) as Predictors of Mortality in Surgical Patients with Complicated IntraAbdominal Infection. Surgical Infections, 2015. 16.

5. L. Smith, P.K., S. Molly, A. Rhodes, P.J Newman, Base excess and lactate as prognostic indicators for patients admitted to intensive care. Intensive Care med, 2001(27:74-83).

6. Moore Keith L, D.A.F., Clinically Oriented Anatomy. Abdomen. Vol. 5. 2006: Lippincott Williams \& Wilkins.

7. Wim De Jong, S.R., Buku Ajar Ilmu Bedah. 2 ed. 2003, Jakarta. 


\section{ARTIKEL PENELITIAN}

8. F. Charles Brunicardi, D.K.A., Timothy R.Biliar, David 1.Dunn, John G. Hunter, Jeffrey B.Matthews, Raphael E. Pollock, Stomach, in Schwartz's Principles of Surgery, M. F. Charles brunicardi, FACS, Editor. 2015, McGraw-Hill: United States.

9. Ebru Menekse, B.K., Ramazan Topcu, Aydemir Olmez, Mesut Tez, Cuneyt Kayaalp, $A$ Practical Scoring System to Predict Mortality in Patients with Perforated Peptic Ulcer. World Journal of Emergency Surgery, 2015.

10. Remco van Horssen, T.N.S., Monique J.M de Groot, Bernadette S. Jakobs Lactate point-of-care testing for acidosis: Cross-comparison of two devices with routine laboratory results. Practical Laboratory Medicine, 2015.

11. Marlene Ersgaard Jelllinge, D.P.H., Peter Hallas, Mikkel Brabrand, Hypoalbuminemia is a Strong Predictor of 30-Day AllCause Mortality in Acutely
Admitted Medical Patients : A Prospective, Observational, Cohort Study. 2014.

12. Gonzalez, Elizondo Vazquez, Garza Maldonado, Hypoalbuminemia in the outcome of patients with nonvariceal upper gastrointestinal bleeding, Cohort studies, 2016.

13. Rajnish K, Jain, Chakravorty N, et all, Albumin : an Overview of Its Place in Current Clinical Practice, 2004, Indian J. Anaesth, 433-438

14. Nocholson, J.P, Wolmarans $\mathrm{M}, \mathrm{R}$, The Role of Albumin in Critical Ilness, $\mathrm{Br} \mathrm{J}$ Anaesth 2000, 85 : 599-610.

15. Lee, Constance W, MD, Sarosi Jr, George, Emergency Ulcer Surgery, Surg Clin North Am. 2013, 91(5).

16. Thorsen, K., J.A. Soreide, and K. Soreide,Scoring systems for outcome prediction in patients with perforated peptic ulcer. Scand J Trauma Resusc Emerg Med 2013;21:25 doi :101186/1757-7241-21-25 


\section{ARTIKEL PENELITIAN}

17. Mishra A, Sharma D, Raina VK. A simplified prognostic scoring system for peptic ulcer perforation in developing countries. Indian J Gastroenterol 2003;22:49-53

18 Lohsiriwat, Varut, Prapasrivorakul, Siriluck. Perforated Peptic Ulcer : Clinical Presentation, Surgical Outcomes, and the Accuracy in Predicting
Postoperative Morbidity and Mortality

19 Svanes, Cicilie. Trends in Perforated Peptic Ulcer : Incidence, Etiology, Treatment, and Prognosis. World J. Surg. 24, $277-283,2000$.

20 Chou, Nan - Hua, Mok, KingTong. Risk factors of mortality in perforated peptic ulcer. European Journal of Surgery, Volume 166, Issue 2. 


\section{ARTIKEL PENELITIAN}

Tabel 1. Mortalitas dan Morbiditas Pasien Perforasi Ulkus Peptikum

\begin{tabular}{|c|c|c|c|c|c|}
\hline \multicolumn{3}{|c|}{ Mortalitas } & \multicolumn{3}{|c|}{ Morbiditas } \\
\hline & Frekuensi & Persentase & & Frekuensi & Persentase \\
\hline Mati & 11 & $27,5 \%$ & $\mathrm{Ya}$ & 7 & $17,5 \%$ \\
\hline Hidup & 29 & $72,5 \%$ & Tidak & 33 & $82,5 \%$ \\
\hline Total & 40 & $100,0 \%$ & Total & 40 & $100,0 \%$ \\
\hline
\end{tabular}

Tabel 2. Jenis Kelamin

\begin{tabular}{|c|c|c|c|}
\hline & \multicolumn{3}{|c|}{ Mortalitas } \\
\hline & Mati & Hidup & Total \\
\hline Perempuan & $2(18,2 \%)$ & $3(10.2 \%)$ & $5(12.5 \%)$ \\
\hline Laki - laki & $9(81.8 \%)$ & $26(89.7 \%)$ & $35(87.5 \%)$ \\
\hline \multirow[t]{3}{*}{ Total } & $11(100 \%)$ & $29(100 \%)$ & $40(100 \%)$ \\
\hline & \multicolumn{3}{|c|}{ Morbiditas } \\
\hline & Ya & Tidak & Total \\
\hline Perempuan & $0(0,0 \%)$ & $5(15.2 \%)$ & $5(12.5 \%)$ \\
\hline Laki - laki & $7(100.0 \%)$ & $28(84.8 \%)$ & $35(87.5 \%)$ \\
\hline Total & $7(100 \%)$ & $33(100 \%)$ & $40(100 \%)$ \\
\hline
\end{tabular}




\section{ARTIKEL PENELITIAN}

Tabel 3. Usia

\begin{tabular}{lrrrrr}
\hline & Mean & SD & Median & Minimum & Maximum \\
& & & & & \\
\hline Total & 59,9 & 14,8 & 61,5 & 22 & 80
\end{tabular}

Mortalitas

$\begin{array}{crrrrr}\text { Mati } & 54,7 & 15,2 & 51 & 22 & 80 \\ \text { Hidup } & 61,9 & 14,5 & 63 & 24 & 80\end{array}$

Morbiditas

$\begin{array}{rrrrrr}\text { Ya } & 65,7 & 7,3 & 63 & 57 & 76 \\ \text { Tidak } & 58,7 & 15,8 & 61 & 22 & 80\end{array}$


Tabel 4. Kadar Laktat dan Albumin

Mean SD $\quad$ Median Minimum Maximum

\begin{tabular}{lllllll}
\hline $\begin{array}{l}\text { Kadar } \\
\text { Laktat }\end{array}$ & Total & $\mathbf{3 , 4}$ & $\mathbf{2 , 8}$ & $\mathbf{2 , 3}$ & $\mathbf{0 , 9}$ & $\mathbf{1 6 , 7}$ \\
$\mathbf{( m m o l} / \mathbf{L})$ & Mortalitas & & & & \\
& Mati & 6,4 & 3,7 & 5,0 & 3,2 & 16,7 \\
& Hidup & 2,2 & 1,1 & 1,9 & 0,9 & 5,7
\end{tabular}

Morbiditas

\begin{tabular}{|c|c|c|c|c|c|c|}
\hline & $\mathrm{Ya}$ & 3,7 & 1,2 & 3,4 & 2,2 & 5,7 \\
\hline & Tidak & 3,3 & 3,1 & 2,1 & 0,9 & 16,7 \\
\hline Kadar & Total & 2,4 & 0,6 & 2,3 & 11 & 3,7 \\
\hline
\end{tabular}

Albumin

$(\mathrm{mg} / \mathrm{dL}) \quad$ Mortalitas

$\begin{array}{rrrrrr}\text { Mati } & 2,1 & 0,4 & 2,2 & 1,3 & 2,7 \\ \text { Hidup } & 2,5 & 0,6 & 2,4 & 1,1 & 3,7\end{array}$

Morbiditas

$\begin{array}{rrrrrr}\text { Ya } & 2,5 & 0,7 & 2,7 & 1,7 & 3,5 \\ \text { Tidak } & 2,4 & 0,6 & 2,3 & 1,1 & 3,7\end{array}$




\section{ARTIKEL PENELITIAN}

Tabel 5 . Perbandingan Kadar Laktat Berdasarkan Mortalitas dan Morbiditas Pasien

\begin{tabular}{lcccccc}
\hline & & N & Mean & SD & Median & P \\
\hline Kadar Laktat & Mortalitas & & & & & \\
$(\mathbf{m m o l} / \mathbf{L})$ & Mati & 11 & 6,4 & 3,7 & 5,0 & 0,000 \\
& Hidup & 29 & 2,2 & 1,1 & 1,9 & \\
& Morbiditas & & & & & \\
& Ya & 7 & 3,7 & 1,2 & 3,4 & 0,0435 \\
& Tidak & 33 & 3,3 & 3,1 & 2,1 & \\
\hline
\end{tabular}

* Uji Mann-Whitney

Tabel 6. Perbandingan Kadar Albumin Berdasarkan Mortalitas dan Morbiditas Pasien

\begin{tabular}{lcccccc}
\hline & & N & Mean & Std. Dev. & Std. Error & p \\
\hline Kadar Albumin & Mortalitas & & & & & \\
$(\mathbf{m g} / \mathbf{d L})$ & Mati & 11 & 2,1 & 0,4 & 0,1323 & 0,0305 \\
& Hidup & 29 & 2,5 & 0,6 & 0,1172 & \\
& Morbiditas & & & & & \\
& Ya & 7 & 2,5 & 0,7 & 0,2543 & 0,707 \\
& Tidak & 33 & 2,4 & 0,6 & 0,1045 & \\
\hline
\end{tabular}

* Uji t independent 


\section{ARTIKEL PENELITIAN}

Tabel 7. Hasil Analisis Regresi Logistik

Hubungan Kadar Laktat dan Albumin dengan Mortalitas Pasien

\begin{tabular}{lcccccc}
\hline & B & Std. Error & Wald & df & P & Exp(B) \\
\hline Laktat & $\mathbf{3 , 5 0 5}$ & $\mathbf{1 , 7 7 2}$ & $\mathbf{3 , 9 1 4}$ & $\mathbf{1}$ & $\mathbf{0 , 0 2 4}$ & $\mathbf{3 3 , 2 9 4}$ \\
Albumin & $\mathbf{- 5 , 2 5 2}$ & $\mathbf{2 , 8 3 8}$ & $\mathbf{3 , 4 2 5}$ & $\mathbf{1}$ & $\mathbf{0 , 0 3 2}$ & $\mathbf{0 , 0 0 5}$ \\
Konstanta & $-1,768$ & 2,651 & 0,445 & 1 & 0,505 & 0,171 \\
\hline
\end{tabular}

* Dependen: Mortalitas

Uji Omnibus: Chi-square $=36,708(\mathrm{p}=0,000)$

Nagelkerke R Square $=0,868$

Tabel 8. Hasil Analisis Regresi Logistik

Hubungan Kadar Laktat dan Albumin dengan Morbiditas Pasien

\begin{tabular}{lcccccc}
\hline & B & Std. Error & Wald & df & p & $\operatorname{Exp(B)}$ \\
\hline Laktat & 0,050 & 0,133 & 0,144 & 1 & 0,352 & 1,052 \\
Albumin & 0,403 & 0,696 & 0,334 & 1 & 0,7185 & 1,496 \\
Konstanta & $-2,721$ & 1,890 & 2,073 & 1 & 0,150 & 0,066 \\
& & & & & & \\
\hline
\end{tabular}

* Dependen: Morbiditas

Uji Omnibus: Chi-square $=0,447(\mathrm{p}=0,800)$

Nagelkerke R Square $=0,018$ 